\title{
Evaluation of the environmental impact of dredging on intertidal coral reefs at Ko Phuket, Thailand, using ecological and physiological parameters
}

\author{
B. E. Brown ${ }^{1}$, M. D. A. Le Tissier ${ }^{1}$, T. P. Scoffin ${ }^{2}$, A. W. Tudhope ${ }^{2}$ \\ ${ }^{1}$ Centre for Tropical Coastal Management Studies, Department of Biology, University of Newcastle upon Tyne, \\ Newcastle upon Tyne NE1 7RU, United Kingdom \\ ${ }^{2}$ Department of Geology, University of Edinburgh, Edinburgh EH9 3JW, Scotland, United Kingdom
}

\begin{abstract}
In 1986-1987 an intertidal reef flat at Phuket. Thailand was subject to increased sedimentation from a 9 mo dredging operation. Reef corals showed as much as a $30 \%$ reduction in living coral cover 1 yr after the start of dredging. Species diversity (measured as the Shannon Weaver indices $\mathrm{H}^{\prime} \mathrm{C}$ and $H^{\prime} n$ ) also showed a significant decline at this time. In particular the dominant coral species on the reef, Porites Iutea, suffered considerable mortality as a result of increased sedimentation. After the event, the reef recovered rapidly with coral cover values and diversity indices restored to former levels ca 22 mo after dredging began. No significant change in the linear growth rate, skeletal density and calcification of $P$. lutea was detected by the methods adopted in this study. Our results indicate that caution should be adopted in the use of retrospective coral growth rate analysis to diagnose the demise of a reef.
\end{abstract}

\section{INTRODUCTION}

Although the effects of sedimentation on reef corals have been widely discussed and reviewed in the literature (see Pastorak \& Bilyard 1985 and Grigg \& Dollar in press for reviews), there are relatively few papers which specifically address the effects of dredging on reef corals at sites where corals have been monitored before, during and after the event. Marzalek (1981) surveyed reef areas before and after a large-scale dredging project off Florida, USA, where dredging took place for 3 mo every year over a 5 yr period. He reported no mass mortality of hard corals after shortterm exposure to sediments (a few days) although several colonies showed partial mortality and excessive mucus secretion after prolonged exposure to siltation. Similarly, no long-lasting effects of sedimentation were evident on coral reefs at Diego Garcia (Indian Ocean) following blasting and dredging in the lagoon (Sheppard 1980).

In Bermuda, Dodge \& Vaisnys (1977) attributed lower amounts of living coral in Castle Harbour, when compared with control reefs, to extensive dredging in the area 35 yr earlier. They also noted slower annual linear extension in colonies of Diploria labyrinthiformis at Castle Harbour prior to death, when compared with earlier growth increments, and ascribed the reduction in skeletal extension to increased sedimentation from dredging. Reduction in other growth parameters, such as calcification, has been similarly ascribed to dredging activities in studies by Bak (1978) and Dodge \& Brass (1984) but these studies provided no information on the status of the coral community either before or after the dredging activity so that community effects could not be compared with those at the colony level.

In the present study deep-water port construction at Phuket, Thailand, during 1986-87, has involved the dredging of 1.3 million $\mathrm{m}^{3}$ of sediment for channel construction and land-fill at a port facility. Coral reefs adjacent to the dredging activity have been regularly monitored over the period 1979 to 1988 . The reefs are dominated by Porites lutea, a massive species which has suffered a considerable decline in abundance during the dredging activity. The present study provided a unique opportunity of combining long-term ecological monitoring before, during and after the dredging 
event with growth rate measurements of $P$. lutea over the same periods.

\section{MATERIAL AND METHODS}

Background history of study sites. In 1986 work began on the construction of a deep water port on the south-east coast of Ko Phuket, at a bay adjacent to Site A (Fig. 1). Sediments for fill were dredged during establishment of deep-water channels in the area. During the dredging operation, which lasted from 21 October 1986 to mid-July 1987, sediment was transported to the fill site at the port. As sediment accumulated behind a containing wall (bund), very fine clay particles escaped

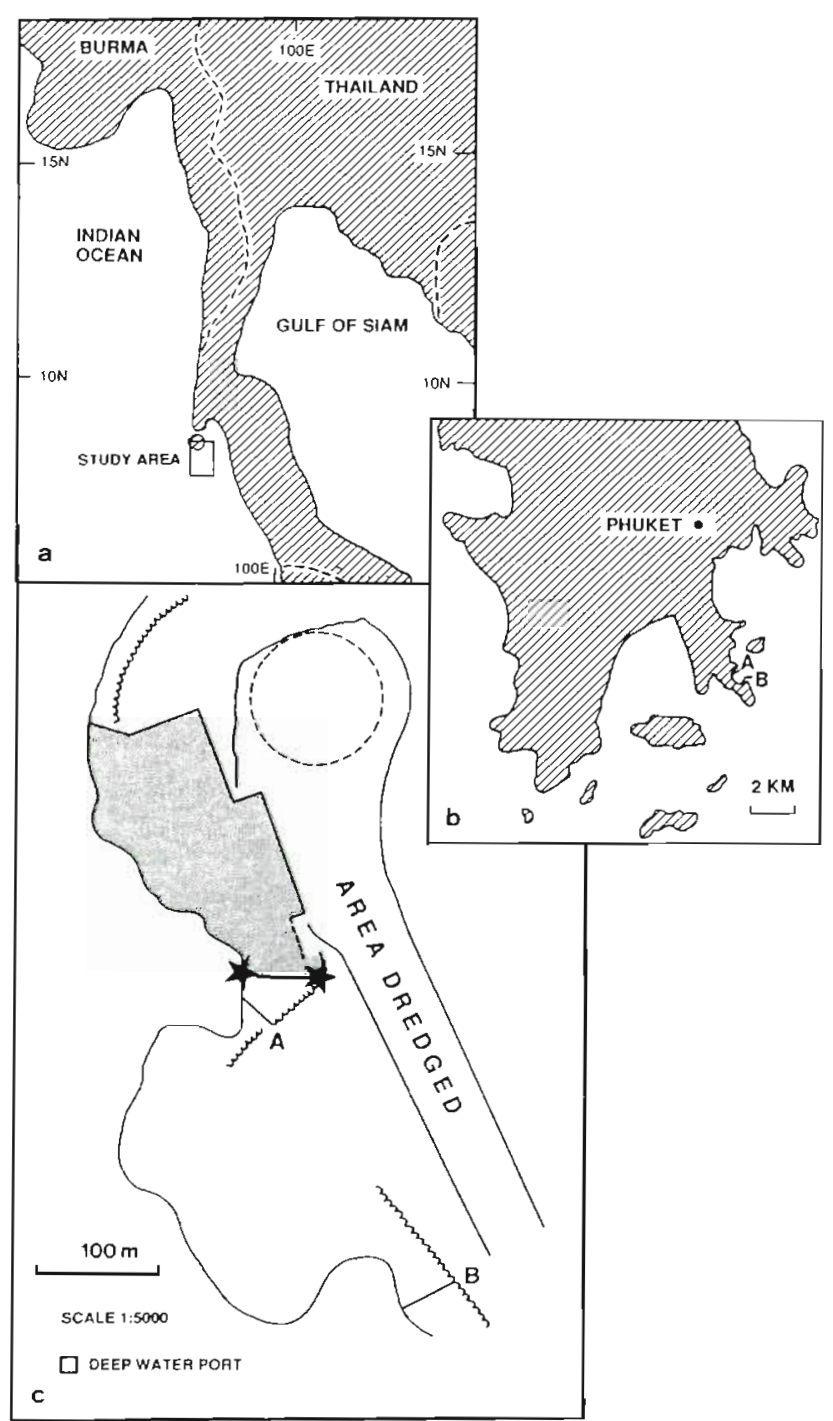

Fig. 1. Location of study sites at Ko Phuket, Thalland. (a) Position of the study area on the west coast of Thailand, (b) location of Sites A and B on Phuket Island and (c) location of the sites with respect to the dredged channel deep-water port and position of the bund $(\star-\star$ ) through the bund and accumulated on the inner reef flat at Site A. The proximity of this site to the dredging operation meant that this location received sediment not only from deep-water channel dredging but also from fill operations behind the bund. Although deep-water channel dredging continued throughout the 9 mo dredging period, leakage of fine sediments from fill activities onto Site $A$ was restricted to a period between October 1986 and January 1987. Site B, although some $800 \mathrm{~m}$ away from the port, is situated on the edge of a channel where tidal currents carry sediment plumes away from the reef front (Ditlev 1978) and appeared to receive relatively low levels of sediment as a result of the dredging operation. Suspended sediment concentrations of up to $286 \mathrm{mg} \mathrm{l}^{-1}$ were recorded on the reef flat at Site A during the dredging operations. Normal suspended sediment concentrations measured at Sites $A$ and B were less than $30 \mathrm{mg} \mathrm{l}^{-1}$ (Brown \& Holley 1982, Scoffin \& Tudhope unpubl.).

Measurement of ecological indices. The community structure of intertidal reef flats around the southeast corner of Ko Phuket has been described elsewhere (Ditlev 1978, Brown \& Holley 1982, 1984) and so only brief details will be presented here. In earlier studies a number of locations in the area were surveyed but in the present study, surveillance was limited to the 2 sites, $A$ and $B$, which have a similar reef flat community, dominated primarily by Porites lutea.

The intertidal reef flats at these locations were originally surveyed in 1979 with surveys repeated in 1983 , 1986 and 1987. Ecological surveillance followed the methods adopted in Brown \& Holley (1982). At Site A in 1979 one line perpendicular to the shore was followed across the reef with $10 \mathrm{~m}$ plotless line transects placed parallel to the shore at $10 \mathrm{~m}$ intervals along the perpendicular line from the inner reef flat to the outer reef edge. A total of seventeen $10 \mathrm{~m}$ transects were monitored on this line. In 1983 the positions of the perpendicular line were fixed with compass bearings on sighted objects and the start and end of each transect line were marked with stainless steel pins hammered into the reef. Although many of the pins were lost in successive years it is estimated, from regular photographic records of permanent transects, that transects were not misplaced by $>0.5 \mathrm{~m}$ from their original positions in subsequent surveys. At Site B 12 permanently marked transects were monitored from 1983 to 1988.

Parameters measured along the transect lines included percentage coral cover of each species and total number of colonies of each species which in turn yielded data on species diversity $\left(H^{\prime}=-\sum p_{1} \log p_{1}\right)$. Shannon and Weaver indices of diversity ( $\mathrm{H}^{\prime} \mathrm{C}$ and $\mathrm{H}^{\prime} \mathrm{n}$ ) were calculated using coral cover and colony number values respectively, as described by Loya (1972). It should be emphasised that coral cover measured by 
methods described above yields estimates of coral cover obtained in only one dimension, i.e. as seen from directly above along the measured line. Living surfaces on the sides of colonies are not recorded and therefore the measure of coral cover is a relative rather than absolute value.

In addition to measurement of ecological indices, 3 permanent belt transects (each measuring $10 \times 1 \mathrm{~m}$ ) were photographed at 6 mo intervals from 1983 to 1988 at Site $A$. The appearance of the reef flats around the southeastern corner of Phuket alters markedly with respect to the amount of sediment covering the corals in the wet and dry monsoon seasons. During the wet monsoon period (May to November) winds are predominantly from the southwest; during the dry monsoon (November to April) the winds are from the northeast. The reefs at Sites $\mathrm{A}$ and $\mathrm{B}$ are sheltered from southwesterly influences during the wet monsoon but during the dry monsoon the northeasterly winds stir up sediments offshore and as a result sedimentation is heavier on these reefs in the dry season than in the wet season (Brown et al. 1986a). The data used in this paper refer only to photographs taken in the wet, southwest, monsoon season when sedimentation is minimum on these reefs. Similarly transect information for percentage live coral cover and species diversity is restricted to data collected between August and November, during the wet monsoon period.

Measurements of skeletal growth in Porites lutea. In order to measure rates of linear growth and calcification over the years prior to, during and following the dredging operation, we employed a method of retrospective skeletal analysis. Nine heads of P. lutea corals, each about $25 \mathrm{~cm}$ diameter, were collected from the reef flat at Site A and 9 from the reef flat at Site B. All corals were cut along their axial regions into slabs about $20 \mathrm{~mm}$ thick, which were bleached, washed and dried at $50^{\circ} \mathrm{C}$. Fluorescent banding (Isdale 1984), visible under ultraviolet light of $365 \mathrm{~nm}$ wavelength, is well developed in $P$. lutea corals in the region. Vital staining with alizarin red S (Barnes 1972) indicated that the banding is seasonal, with a bright and dull band couplet representing ca 1 yr growth; the middle of a dull band being formed in August. We therefore used the fluorescent banding to define 'years' of growth. Although we cannot be certain that each bright-dull couplet represents exactly 12 mo growth, comparisons of fluorescent band patterns with an alizarin red S stain line indicates that the same time intervals were sampled at both the dredged site $(A)$ and the control site (B). By this means it was possible to detect both withinand between-site variations in growth rate.

In addition to measurements of linear growth, blocks of skeleton (volume ca $10 \mathrm{~cm}^{3}$ ), from each of the 3 growth periods, were cut out of the coral slab (see

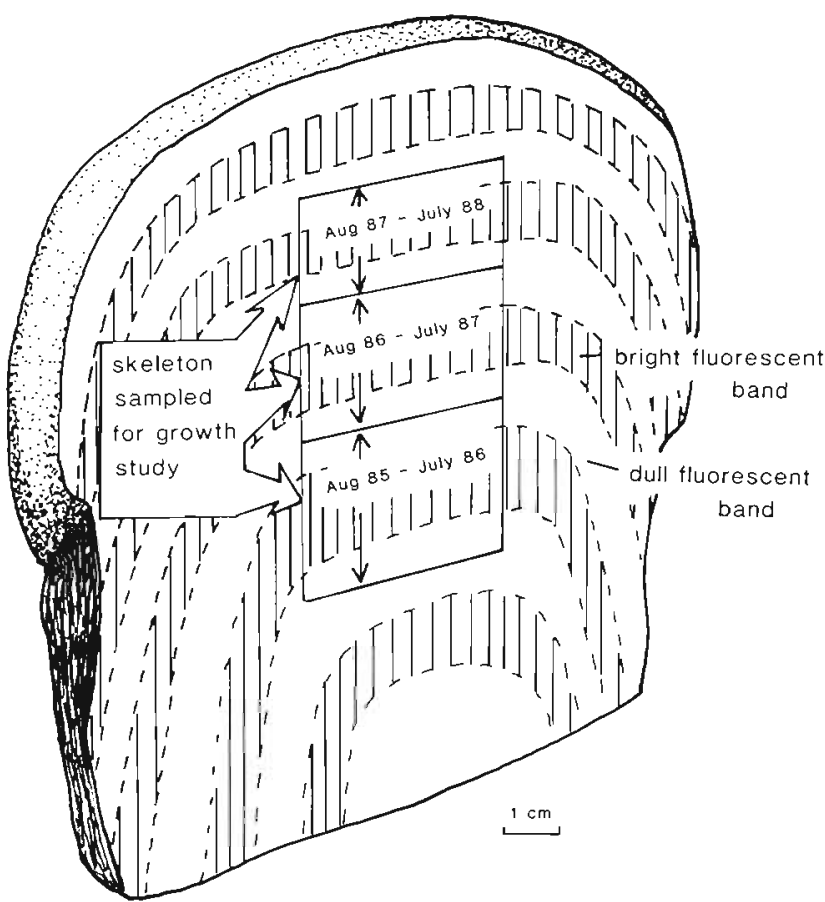

Fig. 2. Porites lutea. Cross-section showing seasonal fluorescent banding and sample block position

Fig. 2) in order to calculate bulk density. For each coral 3 blocks of skeleton were cut out with a hand saw; one block represented growth from August 1985 to July 1986 (a), a second from August 1986 to July 1987 (b) and a third from August 1987 to July 1988 (c). Block (a) represents the year's growth before the dredging event, block (b) represents the years's growth during the dredging event and block (c) represents the year's growth after the dredging event. After drying each block was coated in 2 layers of self-sealing heat-shrunk film (the type used on model aircraft) using a cool iron. The weights of each block in air and water were determined on a balance. Since many of the blocks had bulk densities less than $1 \mathrm{~g} \mathrm{~cm}^{-3}$ they floated in water and the weighings had to be done with a lead weight attached to the block with a thread. The weighings were:

Weight of lead + film + thread in air $=w$

Weight of lead + sample + film + thread in air $=x$

Weight of lead + film + thread in water $=y$

Weight of lead + sample + film + thread in water $=\mathrm{z}$

$$
\begin{aligned}
& x-w=w t \text { of sample in air } \\
& z-y=w t \text { of sample in water }
\end{aligned}
$$

Bulk density
of sample (specific gravity) $=\frac{(x-w)}{(x-w)-(z-y)}$

To obtain weighings ( $w$ ) and (y) the lead weight was coated in 2 layers of the same heat-shrunk film similar in size to that used on the coral blocks. In the weighings with coral samples ( $x$ and $z$ ) the film was removed from 
the lead but was of course present on the coral blocks. Such measurements allowed the calculation of bulk density of that part of the coral for which linear growth was known. Calcification rates (the products of linear extension and density) were calculated for the 3 time periods analysed.

In addition 4 colonies of Porites lutea collected from Site $A$ were cut along their axial regions into $5 \mathrm{~mm}$ thick slabs which were $\mathrm{X}$-radiographed in the manner described in Scoffin et al. (1989a).

\section{RESULTS}

\section{Ecological surveillance}

The dredging event had a pronounced effect upon both coral cover and species diversity at Site A in 1987 data, whereas no similar effect was apparent at Site B (Figs. 3, 4 and 5). Statistical comparison of results using the Wilcoxon Matched-pair Sign Ranked Test (Siegel 1956) revealed that the declines in coral cover and diversity at Site A were significant $(p<0.01)$ when compared with the pre-dredging years 1983 and 1986 and with results obtained after the event in 1988 (Table 1). It should be noted that the reef surveillance in 1986 was carried out at the start of the dredging activities with ecological effects apparent at Site $\mathrm{A}$ in 1987. By this time Porites lutea, which had previously been dominant on the reef flat, had declined by as much as $25 \%$ of its former coverage (Table 2). Other massive corals, particularly the favidd genera Goniastrea, Platygyra, Leptastrea, Favia, and Favites, also showed a marked decline in abundance at this time. Branching Acropora species, on the other hand, which have a limited cover on this reef, do not appear to have been adversely affected by the dredging activities. At Site B no significant differences in coral cover and species diversity were evident in the monitoring period 1983 to 1987.

By 1988 coral recovery at Site A was well underway for all massive species affected by the short-term dredging event -- in particular Porites lutea had made a spectacular recovery to former levels of abundance. Although it is recognised that $P$. lutea is capable of remaining alive beneath sediment for several weeks (Stafford-Smith pers. comm.), photographic records throughout the study period indicate that reductions in living cover recorded for this and other massive species were due to death of the living tissues with colonies being covered by sediment for over 18 mo in many cases (Fig. 6). Interestingly, coral cover and diversity at Site B in 1988 had altered in comparison with earlier years, with significant increases in $P$. lutea cover and a significant decrease in species diversity as a result of

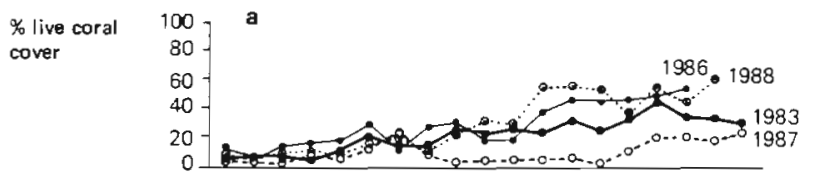

Species
diversity

(H'n)

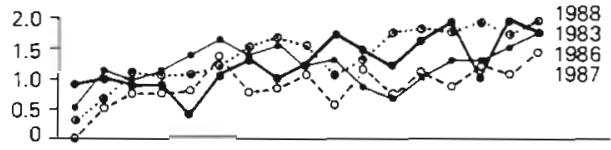

Species diversity (H'c)
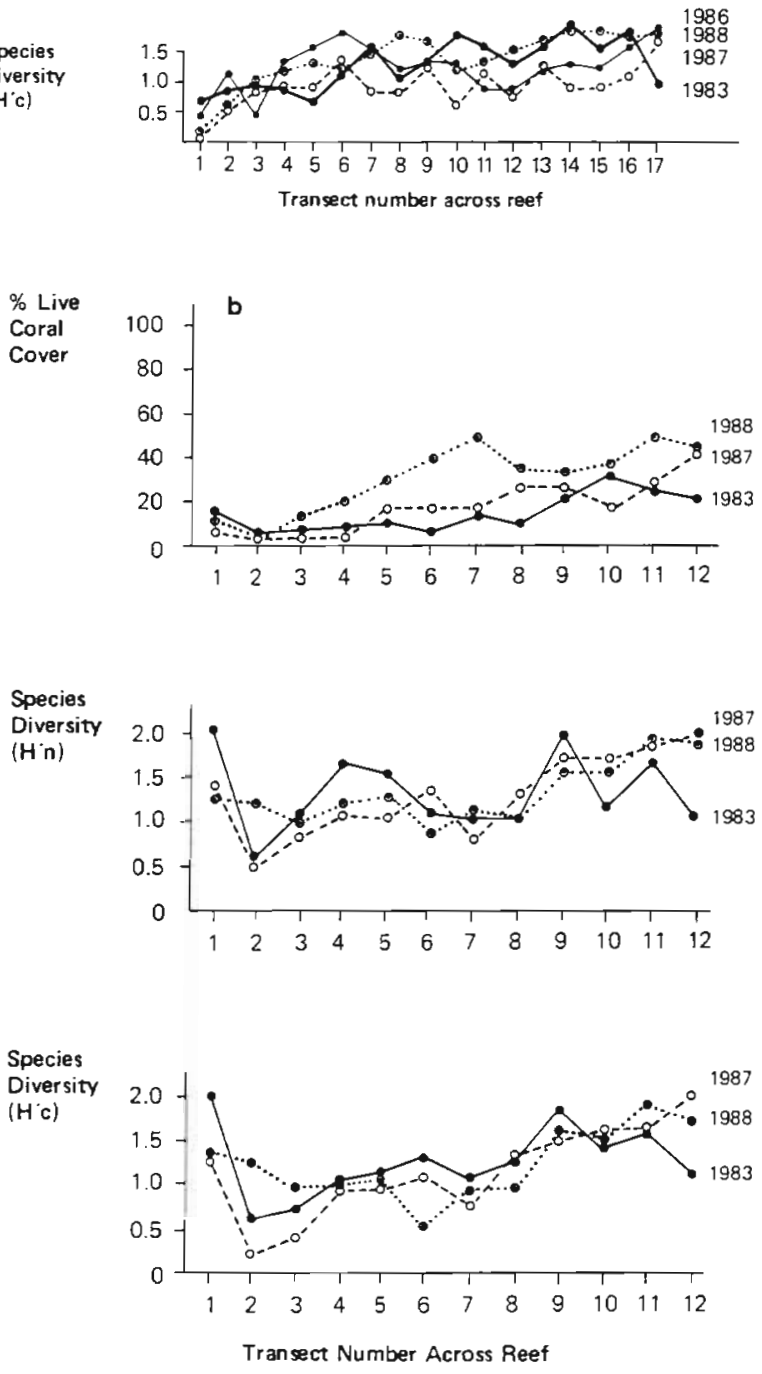

Fig. 3. Plots of percentage coral cover, and species diversity (as $\mathrm{H}^{\prime} \mathrm{C}$ and $\mathrm{H}^{\prime} \mathrm{n}$ ) for transects across the reef at (a) Site A and (b) Site B over the period 1983 to 1988

greater dominance on the transects of this species. Factors responsible for this are not clear but appear to be related to some local characteristic since nearby reefs show similar patterns of increased live coverage by Porites lutea over the same period. 

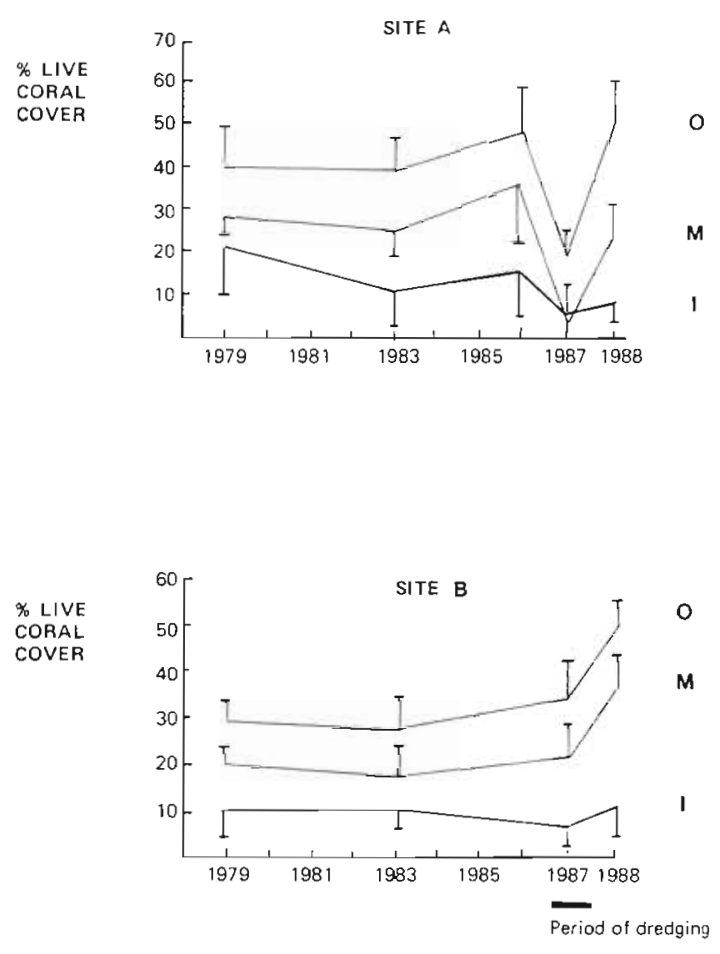

Fig. 4. Overall changes in mean percentage coral cover for inner (I), mid (M) and outer (O) reef flat at (a) Site A and (b) Site $\mathrm{B}$ over the period 1983 to 1988. Standard deviations are shown; $\mathrm{n}=6$ for inner and mid reef flat at Site $A, n=5$ for outer reef flat at Site $A, n=4$ for inner, mid and outer reef flat at Site B
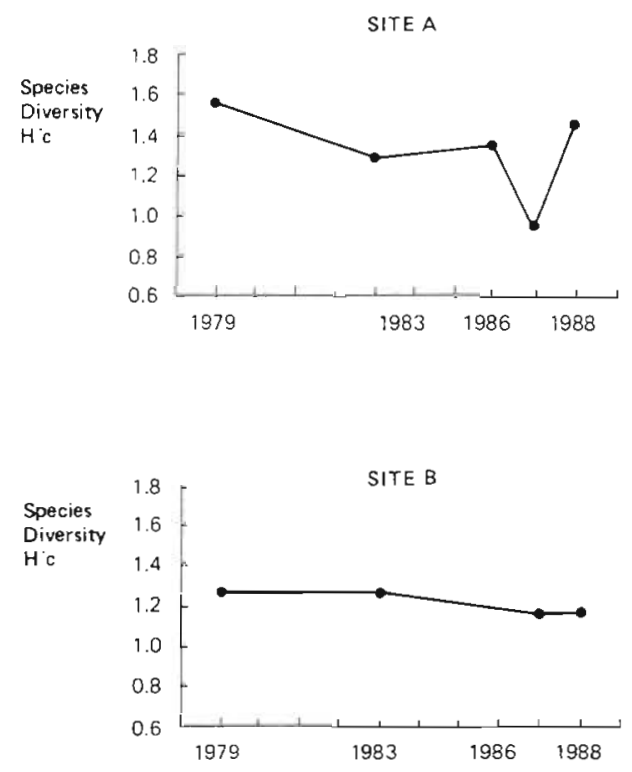

Fig. 5. Overall changes in species diversity (plotted as $\mathrm{H}^{\prime} \mathrm{c}$ ) at (a) Site A and (b) Site B over the period 1983 to 1988

\section{Coral skeletal growth}

The mean linear growth, density and calcification rates of Porites lutea skeleton from Sites A and B over the monitoring periods are illustrated in Fig. 7. Average annual linear growth rates were high, ranging from 12.0 to $30.0 \mathrm{~mm} \mathrm{yr}^{-1}$. When the data are analysed using

Table 1. Statistical significance of paired comparison between years of (a) percentage coral cover and (b) species diversity as $\mathrm{H}^{\prime} \mathrm{C}$ and $H^{\prime} n$ at Sites A and B. (p values given for Wilcoxon Matched-pair Sign Ranked Test) over the period 1983 to 1988

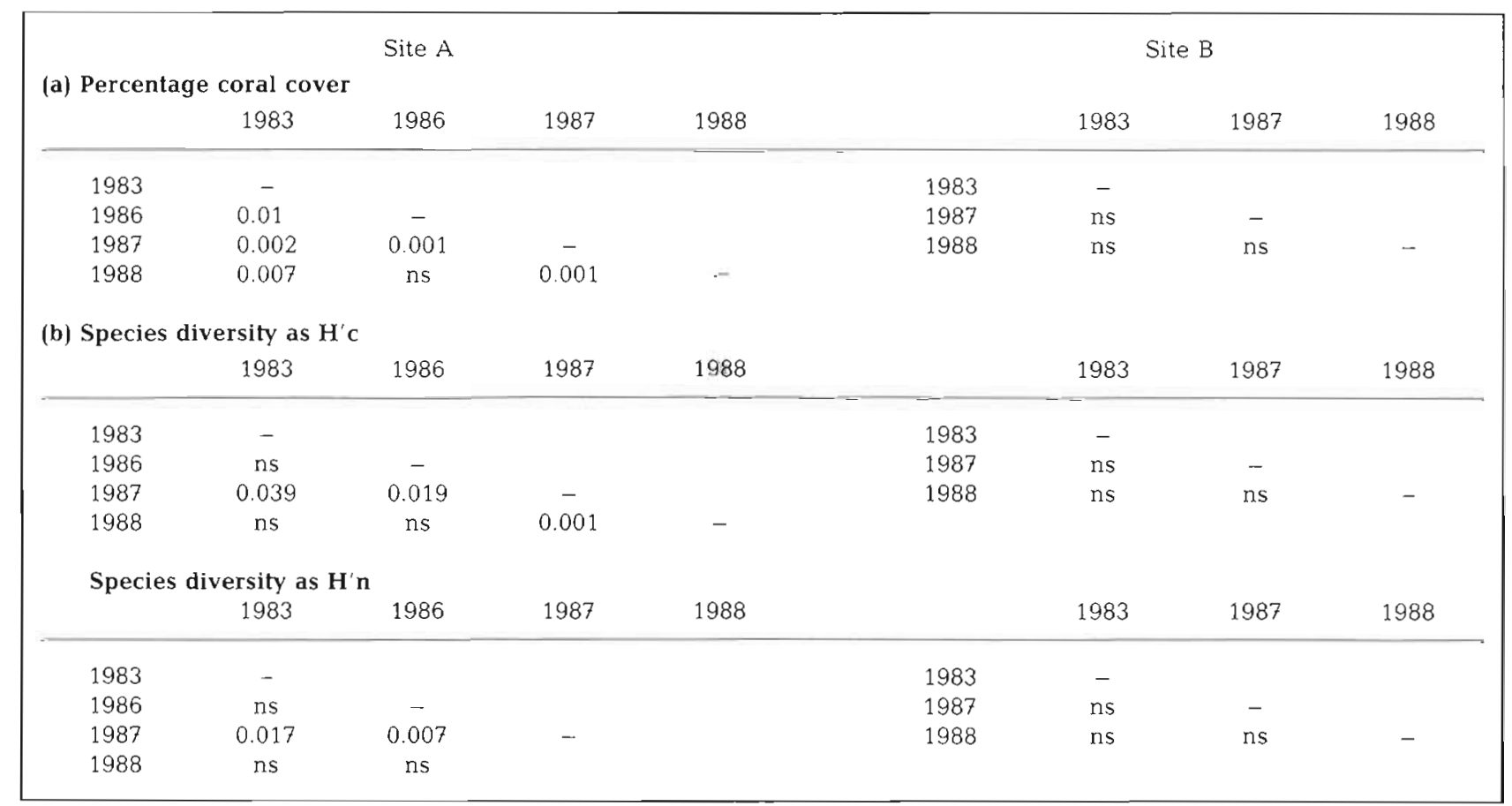



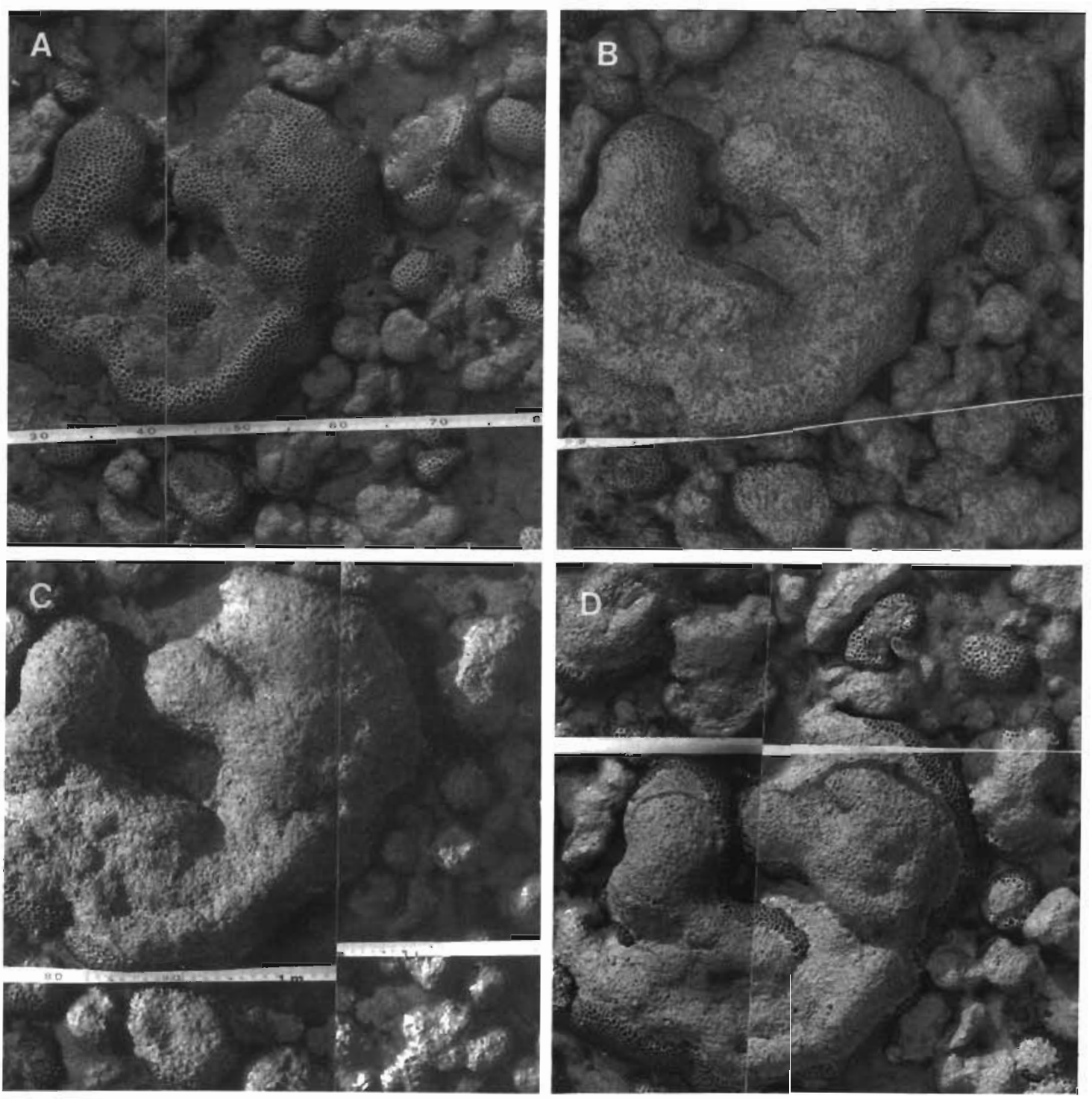

Fig. 6. Selected area on permanent photographic transect at Site A at regular intervals through the study period. (A) August 1986 (2 mo before dredging began); (B) November 1986 (1 mo after dredging started); (C) January 1988 (6 mo after dredging completed); (D) August 1988 (12 mo after dredging completed)

a Kruskal Wallis test (Sokal \& Rohif 1981) to compare 'growth' over the 3 time periods analysed, there are no significant differences $(p>0.05)$ in any of the measured growth parameters between years at either Site A or Site B, despite the fact that Site $A$ was adversely affected by dredging while no deleterious ecological effects were apparent at Site B. Significant differences in linear growth $(\mathrm{p}<0.002)$ and calcification rate $(\mathrm{p}<$ 0.001 ) were apparent between Sites $A$ and $B$ when data for all time periods were compared, with Site B showing consistently higher linear growth and calcification rates when compared with Site A. Reasons for the intrinsically higher growth rate of corals at Site $B$ were not investigated in this study but are reported in another paper (Scoffin et al. 1989b, Scoffin et al. unpubl.).

We examined $\mathbf{X}$-radiographs of 4 surviving Porites lutea corals to see if the dredging event was recorded by particularly dense skeleton, analogous to the socalled 'stress bands' of Hudson (1977, 1983). The Xradiographs revealed that, although the density banding pattern of these intertidal corals was very complex with several fine, dense bands being produced each year (when the year in which dredging took place was compared to previous years), no conspicuous signal of the dredging event was evident (Fig. 8). 
Table 2. Total cover ( $m$ ) of coral species on all transects at Sites A and B during the period 1983 to 1988

\begin{tabular}{|c|c|c|c|c|}
\hline \multicolumn{5}{|l|}{ Site A } \\
\hline Species & 1983 & 1986 & 1987 & 1988 \\
\hline Porites lutea & 11.52 & 23.00 & 5.00 & 17.70 \\
\hline Porites murrayensis & 4.03 & 3.60 & 2.00 & 5.70 \\
\hline Porites andrewsii & 0.77 & 0.02 & 0.01 & 2.80 \\
\hline Goniastrea favulus & 7.98 & 3.99 & 5.08 & 4.47 \\
\hline Goniastrea aspera & 3.20 & 3.54 & 0.84 & 2.62 \\
\hline Goniastrea retiformis & 4.72 & 2.57 & 0.42 & 4.20 \\
\hline Leptastrea transversa & 1.45 & 2.04 & 0.93 & 1.57 \\
\hline Platygyra daedalea & 2.30 & 3.92 & 0.86 & 2.46 \\
\hline Favia pallida & 0.89 & 0.98 & 0.01 & 0.14 \\
\hline Favites abdita & 1.00 & 2.29 & 0.18 & 2.98 \\
\hline Coeloseris mayeri & 1.93 & 0.36 & 0.54 & 0.75 \\
\hline Montipora digitata & 0.04 & 0.10 & 0.01 & 0.14 \\
\hline Acropora aspera & 0.32 & 0.50 & 0.74 & 0.53 \\
\hline \multicolumn{5}{|l|}{ Site B } \\
\hline Species & 1983 & \multicolumn{2}{|c|}{1987} & 1988 \\
\hline Porites lutea & 3.19 & \multicolumn{2}{|c|}{6.06} & 17.05 \\
\hline Porites murrayensis & 0.10 & \multicolumn{2}{|c|}{0} & 0.19 \\
\hline Porites andrewsii & 0.30 & \multicolumn{2}{|c|}{0} & 0.36 \\
\hline Goniastrea favulus & 1.23 & \multicolumn{2}{|c|}{0.55} & 1.10 \\
\hline Goniastrea aspera & 0.45 & \multicolumn{2}{|c|}{0.57} & 0.43 \\
\hline Goniastrea retiformis & 2.92 & \multicolumn{2}{|c|}{2.19} & 1.27 \\
\hline Goniastrea edwardsii & 0.10 & \multicolumn{2}{|c|}{1.31} & 0.15 \\
\hline Leptastrea transversa & 0.48 & \multicolumn{2}{|c|}{2.29} & 0.24 \\
\hline Platygyra daedalea & 1.87 & \multicolumn{2}{|c|}{0.54} & 0.65 \\
\hline Favia abdita & 0.58 & \multicolumn{2}{|c|}{0.31} & 2.54 \\
\hline Coeloseris mayeri & 4.29 & \multicolumn{2}{|c|}{0.43} & 4.14 \\
\hline Montipora digitata & 0 & \multicolumn{2}{|c|}{0.06} & 0.01 \\
\hline Acropora aspera & 2.54 & \multicolumn{2}{|c|}{4.07} & 3.18 \\
\hline Acropora pulchra & 0.40 & \multicolumn{2}{|c|}{0} & 0.38 \\
\hline Pocillopora damicornis & 0.19 & \multicolumn{2}{|c|}{0.43} & 1.26 \\
\hline Fungia fungites & 0.14 & \multicolumn{2}{|c|}{0.67} & 0.59 \\
\hline Psammacora contigua & 0.87 & \multicolumn{2}{|c|}{0.47} & 1.03 \\
\hline
\end{tabular}

\section{DISCUSSION}

The dredging event described in the present study clearly caused a measurable decrease in coral diversity and coral cover on intertidal reef flats at Ko Phuket. The extent of the ecological effects was very similar to that recorded by Amerson \& Shelton (1976) at Johnstone Atoll in the Pacific where siltation, resulting from airfield construction activities, caused a $40 \%$ reduction in coral cover. Unfortunately, the latter example provides no follow-up information on reef status after the initial effects were monitored. In the present study recovery of reef flats damaged by sedimentation was very rapid, taking less than 22 mo to effect. Such rapid recovery may be attributed to the powerful regenerative powers of surviving corals (Bak \& Steward-van Es 1980. Bak 1983). The affected intertidal reef flat at Phuket was dominated by massive corals, many of which suffered only partial mortality as a result of
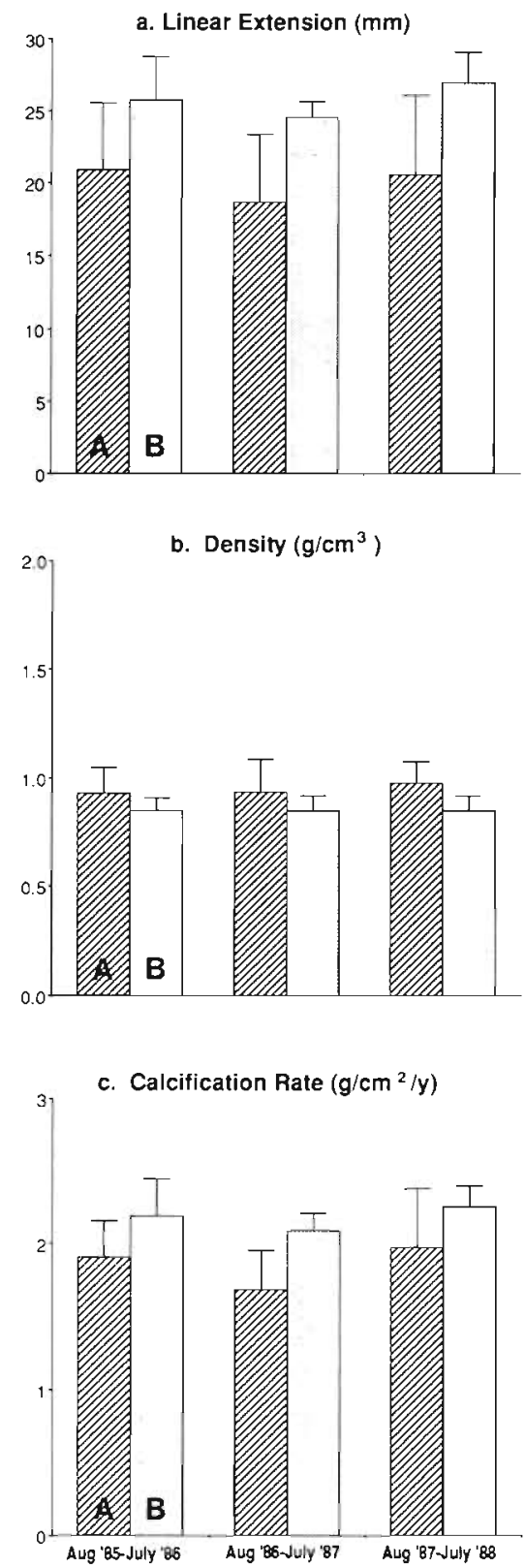

Fig. 7. Porites lutea. Growth at Sites A and B over the periods August 1985 to July 1986, August 1986 to July 1987, August 1987 to July 1988. (a) Linear extension (mm); (b) density ( $\left.\mathrm{g} \mathrm{cm}^{-3}\right)$; (c) calcification rate $\left(\mathrm{g} \mathrm{cm}^{-2} \mathrm{yr}^{-1}\right)$. All values shown as means (+ standard deviation): $n=9($ Site $A) ; n=9($ Site $B)$

dredging. Regular photographic monitoring of transects at this site over the period 1979 to 1985 has already demonstrated the capacity of selected massive species to regenerate living tissues over formerly dead surfaces (Brown et al. 1986b). Such tissue regeneration would provide a means of rapid recovery after a shortterm stressful event (Highsmith 1982).

Though the dredging event clearly caused a measurable decrease in coral diversity and percentage coral 


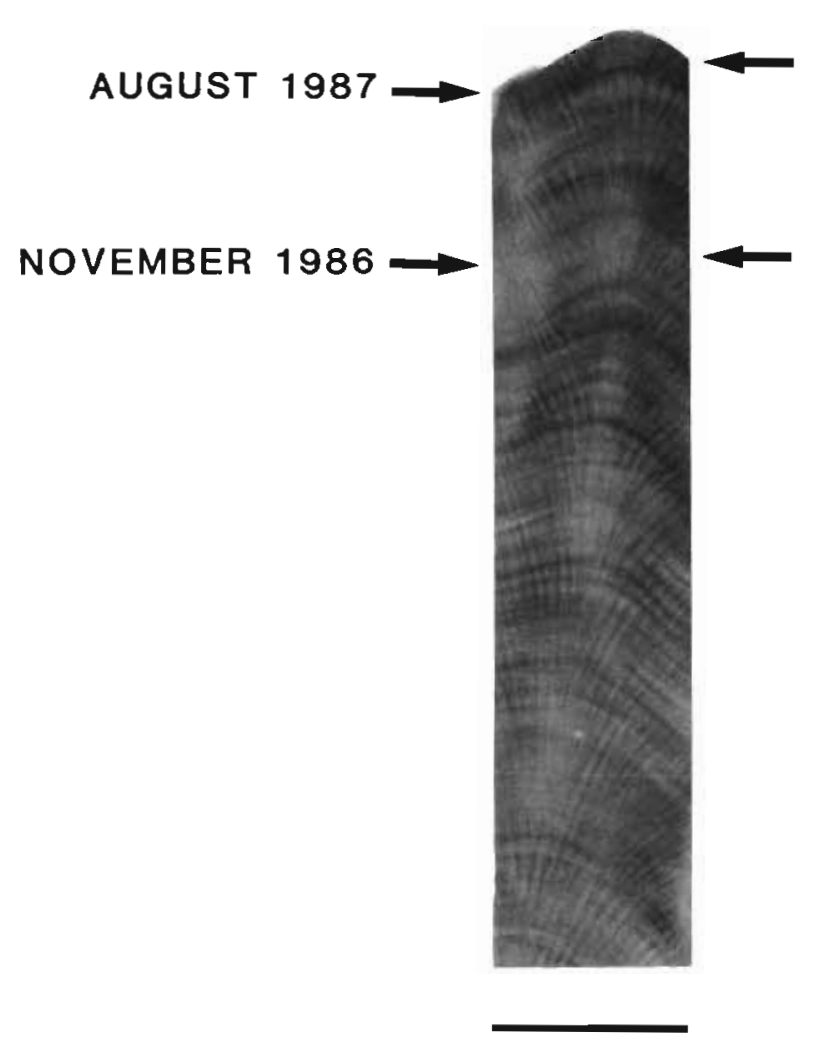

Fig. 8. Porites lutea. X-radiograph of $5 \mathrm{~mm}$ thick slice, collected in August 1987 from Site A. November 1986 position within the skeleton was ascertained by alizarin red $\mathrm{S}$ staining. Note that although density banding is apparent no distinctive density effect is recorded coincident with the dredging event. Scale bar $=2 \mathrm{~cm}$

cover at Site A, no significant change in the growth rate, skeletal density and calcification rate of Porites Iutea was detected by the methods adopted in the study. It may be that fatally high concentrations of sediment occurred for only short periods of time (days to weeks) during the dredging event. If so, any accompanying decrease in growth rate of those corals which survived could have been of too short a duration to noticeably affect the annual coral growth rate. In this context it is interesting that dense stress bands were not apparent in the coral skeletons, although their absence cannot be considered conclusive evidence that such short-lived high sedimentation events did not occur. Our results indicate that caution should be adopted in the use of retrospective coral growth rate analysis to diagnose the demise of a reef.

Acknowledgements. We thank the Director and staft of the Phuket Marne Biological Centre for their contınued support. particularly Dr. Hansa Chansang and Mr Niphon Phongu-wan. We are grateful also to the Natural Environment Research Council, UK who funded this project through NERC grants Nos. GR3/5857 (B.E.B., T.P.S., A.W.T.) and GT5/F/86/ALS/1 (M.T.)

\section{LITERATURE CITED}

Amerson, A. B., Shelton, P. C. (1976). The natural history of Johnstone Atoll, central Pacific Ocean. Atoll Res. Bull. 192: 479

Bak, R. P. M. (1978). Lethal and sublethal effects of dredging on reef corals. Mar. Pollut. Bull. 9: 14-16

Bak, R. P. M. (1983). Neoplasia, regeneration and growth in the reef-building coral Acropora palmata. Mar. Biol. 77 . 221-227

Bak, R. P. M., Steward-van Es, Y (1980). Regeneration of superficial damage on the scleractinian corals Agaricia agaricites, f. purpurae and Porites asteroides. Bull. mar. Sci. 30: 883-887

Barnes, D. J. (1972). The structure and formation of growthridges in scleractinian coral skeletons. Proc. R. Soc. Lond. (Ser. B) 182: 331-350

Brown, B. E., Holley, M. C. (1982). Metal levels associated with tin dredging and smelting and their effect upon intertidal reef flats at Ko Phuket, Thailand. Coral Reefs 1 131-137

Brown, B. E., Holley, M. C. (1984). Coral assemblages of intertidal reef flats at Ko Phuket, Thailand. Phuket Marine Biol. Centre Bull. 30: 1-10

Brown, B. E., Le Tissier, M. D. A., Howard, L. S., Charuchinda M., Jackson, J. A. (1986a). Asynchronous deposition of dense skeletal bands in Porites lutea Edwards and Haime. Mar. Biol. 93: 83-89

Brown, B. E., Howard, L. S., Le Tissier, M. D. A. (1986b) Variation in the dominance and population structure of intertidal corals around Ko Phuket, Thailand. Phuket Marine Biol. Centre Bull. 41: 1-9

Ditlev, H. (1978). Zonation of corals (Scleractinia: Coelenterata) on intertidal reef flats at Ko Phuket, Eastern Indian Ocean. Mar Biol. 47: 29-39

Dodge, R. E., Brass, G. W. (1984). Skeletal extension, density, and calcification of a reef coral (Montastrea annularis): St. Croix, U.S. Virgin Islands. Bull. mar. Sci. 34: 288-307

Dodge, R. E., Vaisnys, J. R. (1977). Coral populations and growth patterns: responses to sedimentation and turbidity associated with dredging. J. mar. Res. 35: 715-730

Grigg, R. W. Dollar, S. J. (in press). Natural and anthropogenic disturbance on coral reefs. Coral Reefs

Highsmith, R. C. (1982). Reproduction by fragmentation in corals. Mar. Ecol. Prog. Ser. 7: 207-226

Hudson, J. H. (1977). Long-term bioerosion rates on a Florida reef. A new method. Proc. 3rd Int. Coral Reef Symp. Miami 2: $491-497$

Hudson, J. H. (1983). Response of Montastrea annularis to environmental change in the Florida Keys. Proc. 4th Int. Coral Reef Symp. Manila 2: 233-240

Isdale, P. (1984). Fluorescent bands in massive corals record centuries of coastal ramfall. Nature, Lond. 310: 578-579

Loya, Y (1972). Community structure and species diversity of hermatypic corals at Eilat, Red Sea. Mar Biol. 13: $100-123$

Marsalak, D. S. (1981). Impact of dredging on a sub-tropical reef community, southeast Florida, U.S.A. Proc. 4th Int. Coral Reef Symp. Manila 1: 147-154

Pastorak, R. A., Bilyard, G. R. (1985). Effects of sewage pollution on coral-reef communities. Mar. Ecol. Prog. Ser 21 $175-189$

Siegel, S. (1956). Nonparametric statistics. McGraw-Hill, New York

Scoffin, T P. Tudhope, A. W., Brown, B. E. (1989a). Fluorescent and skeletal banding in Porites lutea from Papua New Guinea and Indonesia. Coral Reefs 7. 169-178 
Scoffin, T. P., Tudhope, A. W., Brown, B. E. (1989b). Corals as environmental indicators, with preliminary results from South Thailand. Terra Nova 1: 559-563

Sheppard, C. R. C. (1980). Coral fauna of Diego Garcia lagoon,

This article was submitted to the editor following harbour construction. Mar. Pollut. Bull. 11: $227-230$

Sokal, R. R., Rohlf, F. J. (1981). Biometry. W. H. Freeman and Co., San Francisco

Manuscript first received: June 5, 1989 Revised version accepted: May 30, 1990 